Piotr Krakowiak*

Toruń

Barbara Łukaszewska**

Toruń

\title{
Samoocena pracowników w instytucjach edukacyjnych i pomocowych a ich działalność zawodowa***
}

Samoocena pełni istotną rolę w każdej działalności związanej z interakcją międzyludzką. Szczególnie ważna staje się umiejętność samooceny w całej rodzinie zawodów pomocowych (helping professions), do których można zaliczyć zarówno działania edukacyjne i pedagogiczne, jak i wszelkie działania pomocowe. W tym kontekście pojawiają się pytania: jakie są definicje i etiologia samooceny według poszczególnych nurtów teoretycznych?; czy samoocena i jej wybrane wskaźniki, takie jak poziom czy stabilność, mają wpływ na pracę profesjonalistów oraz oferowane przez nich działania pomocowe i edukacyjne?

* Dr hab. Piotr Krakowiak jest pracownikiem Wydziału Nauk Pedagogicznych Uniwersytetu Mikołaja Kopernika w Toruniu, Katedra Pracy Socjalnej. Adres: Wydział Nauk Pedagogicznych UMK, ul. Lwowska 1,87-100 Toruń; e-mail: pkrakow@umk.pl.

** Mgr Barbara Łukaszewska jest psychologiem w Hospicjum „Światło” w Toruniu. Adres: Wydział Nauk Pedagogicznych UMK, ul. Lwowska 1, 87-100 Toruń; e-mail: b.luk@, doktorant.umk.pl.

*** Artykuł powstał w ramach prac i dyskusji na seminarium doktoranckim w UMK. Wkład poszczególnych autorów w powstanie tekstu: dr hab. Piotr Krakowiak: 30\% - współautor koncepcji tekstu oraz założeń metodologicznych, schematu tekstu i jego abstraktu, mgr Barbara Łukaszewska: 70\% - współautorka koncepcji tekstu, autorka badań, których wybór został wykorzystany w przygotowaniu niniejszego tekstu, jego schematu i poszczególnych jego elementów. 
W niniejszym artykule autorzy podejmują próbę odpowiedzi na zadane pytania, traktując samoocenę jako ewaluatywny komponent struktury „Ja”. Tekst stanowi swoisty przegląd teorii i badań naukowych, poczynionych na gruncie polskim i zagranicznym. Zebrane materiały dotyczą następujących zagadnień: pojęcia „Ja” oraz samooceny, jak również poziomu, jasności i stałości samooceny w kontekście budowania relacji pomocowej. Najpierw zajmiemy się pokrótce strukturą „Ja”, ponieważ kluczowe dla samooceny jest poznanie i zaakceptowanie własnej osobowości, czyli struktury „Ja”.

\section{Samoocena w strukturze „Ja”}

Samoocena stanowi ewaluatywny składnik rozbudowanej struktury „Ja”. W literaturze psychopedagogicznej można odnaleźć różne definicje samooceny. Reykowski definiuje ją jako ocenę samego siebie (własnej osoby) i swoich możliwości, która powstaje poprzez uogólnienie ocen siebie w różnych sferach $^{1}$. Wojciszke natomiast rozumie samoocenę jako afektywną reakcję w stosunku do własnego „Ja”2.

Sądy jednostki o sobie mogą mieć zarówno charakter deskryptywny, jak i ewaluacyjny (wartościujący). Afektywne sądy (postawę) podmiotu wobec samego siebie nazywa się samooceną. Sądy na temat własnej osoby, podobnie jak schematy poznawcze, mają strukturę hierarchiczną, w której ocena poszczególnych zachowań składa się na ocenę globalną. Cząstkowe oceny funkcjonowania, dotyczące na przykład kontaktów interpersonalnych, zdrowia fizycznego, pracy zawodowej, tworzą razem zgeneralizowany poziom samooceny, jakim jest samoocena globalna (ogólna) ${ }^{3}$.

Duże znaczenie dla nauk psychopedagogicznych ma fakt, iż „Ja” jest po części uwarunkowane również kulturowo, a niewątpliwy wpływ na jego zawartość mają porównania społeczne, gdy jednostka kształtuje swoją samoocenę poprzez pryzmat bycia lepszą lub gorszą w danej dziedzinie. Struktura

1 Janusz Reykowski, „Obraz własnej osoby jako mechanizm regulujący postępowanie”, Kwartalnik Pedagogiczny 3 (1970): 47n.

2 Bogdan Wojciszke, „Pogranicze Psychologii osobowości i społecznej: samoocena jako cecha i motyw”, w: Osobowość a procesy psychiczne i zachowanie, red. Bogdan Wojciszke, Mieczysław Plopa (Kraków: Oficyna Wydawnicza Impuls, 2003), 15.

${ }^{3}$ Diana Fecenec, Wielowymiarowy Kwestionariusz Samooceny MSEI. Polska adaptacja. Podręcznik (Warszawa: Pracownia Testów Psychologicznych, 2008), 8-18. 
ta tworzy się nieco inaczej wśród członków kultury indywidualistycznej, takiej jak polska czy amerykańska, oraz odmiennie w kulturze kolektywistycznej (dalekowschodniej lub afrykańskiej). Społeczeństwo indywidualistyczne kładzie główny nacisk na jednostkę, podkreślając jej niepowtarzalność, odrębność, niezależne cechy oraz wartości bezpośrednio służące człowiekowi. Przeciwstawny punkt widzenia zaznacza się natomiast wśród społeczeństw kolektywistycznych, które bazują na przynależności grupowej, harmonii społecznej oraz wartościach mających na celu dobro wspólnoty. Dlatego właśnie w kulturze indywidualistycznej jednostka spostrzega siebie jako bardziej odmienną od innych, a pozostałych, jako bardziej podobnych do siebie, zaś w kulturach kolektywistycznych tendencja ta przyjmuje odwrotny kierunek $^{4}$.

\subsection{Pojęcie „Ja” w nurtach psychologicznych}

Pojęcie „Ja” w naukach humanistycznych i społecznych kształtowało się na przestrzeni lat w miarę rozwoju dyscypliny naukowej. Dociekania związane z naturą ,Ja” absorbowały już filozofów, takich jak Arystoteles czy Kartezjusz. Jednak wysoką rangę oraz definicję zbliżoną do współczesnego pojmowania nadał mu dopiero Wiliam James. Dokonał on wówczas podziału na „Ja Poznające” (jednostkę, która posiada wiedzę) i „Ja Przedmiotowe” (przedmiot poznania) oraz podkreślił znamienną rolę $\mathrm{w}$ regulacji zachowania człowieka ${ }^{5}$.

Pojęcie „Ja” stanowiło podstawę teorii Zygmunta Freuda. W teoriach psychoanalitycznych zyskało nazwę , ego" i zostało podzielone na trzy walczące ze sobą struktury psychiki człowieka: id, ego i superego. Podmioty te walczą ze sobą, a jednostka narażona na sprzeczne popędy zaczyna odczuwać lęk. System ego musi zatem doprowadzić do równowagi pomiędzy pierwotnymi popędami oraz wymaganiami kultury, dlatego wytwarza odpo-

${ }^{4}$ Liwei Zhang, ,Prediction of Chinese life satisfaction: Contribution of collective selfesteem”. International Journal of Psychology 3 (2005): 189-200; David P. Schmitt, Juri Alik, „Simultaneous Administration of Rosenberg Self-Esteem Scale in 53 Nations: Exploring the Universal and Culture-Specific Features of Global Self-Esteem", Journal of Personality and Social Psychology 4 (2005): 623-642.

${ }^{5}$ Roy F. Baumeister, „Ego Depletion and the Self's Executive Function”, w: Psychological perspectives on Self and Identity, red. Abraham Tesser, Richard B. Felson, Jerry M. Suls (Washington: APA, 2004), 9-33. 
wiednie mechanizmy obronne, takie jak na przykład humor, racjonalizacja czy anulowanie ${ }^{6}$.

$\mathrm{Na}$ fundamencie teorii psychoanalitycznych powstały kolejne koncepcje teoretyczne tak zwanych neofreudystów. W myśl ich rozważań centralną część „Ja” stanowi self. Carl Gustav Jung twierdził, iż self pozostaje strukturą, która jako jedyna jest w stanie koordynować działanie pozostałych komponentów osobowości. Harry Sullivan pojmował self jako zbiór reprezentacji jednostki w formie trzech personifikacji: „Ja-dobry”, „Ja-zły”, „Nie-Ja”. Dopiero Heinz Hartmann uznał, iż obronne motywacje ego mogą popychać jednostkę ku działaniu użytecznemu i racjonalnemu. Osoba o silnym ego nie musi bowiem inwestować energii w obronę, lecz może przeznaczyć ją do osiagania osobistych celów życiowych, takich jak podwyższenie swojej pozycji społecznej, osiąganie sukcesów i rozwój osobisty?

Pojęcie „Ja” analizowane było także przez przedstawicieli psychologii humanistycznej. Według Carla Rogersa „Ja” krystalizuje się w okresie dorastania. Jednostka wyodrębnia doświadczenia, które są z nią bezpośrednio związane oraz nadaje im znaczenie. Do budowania samoakceptacji i scalania sądów dotyczących cech własnych oraz relacji z innymi ludźmi potrzebna jest akceptacja ze strony otoczenia (zwłaszcza rodziców lub najbliższych osób znaczących). W teorii Rogersa człowiek kieruje się tak zwaną zasadą zgodności, dzięki której zapamiętuje i uświadamia sobie jedynie te doświadczenia, które są zgodne z nabytym wcześniej pojęciem „Ja"8.

Pojęcie „Ja” rozumiane było odmiennie przez określone nurty psychologiczne, zyskiwało odmienną nomenklaturę oraz komponenty. Behawioryści niemalże całkowicie porzucili koncepcję „Ja”, definiując człowieka jako jednostkę podatną na uczenie, złożoną z nawyków i odruchów. Dopiero tak zwana rewolucja poznawcza ponownie zwróciła uwagę naukowców na problematykę związaną z kontraktem „Ja”. Zgodnie z nurtem psychologii poznawczej, jednostka aktywnie pobiera, przetwarza i integruje informacje o sobie i otaczającym świecie, pochodzące z otoczenia zewnętrznego, a także z obserwacji własnych zachowań stanów psychicznych. Dane te nie stanowią zbioru obiektywnych faktów, lecz subiektywną interpretację jednost-

${ }^{6}$ Calvin S. Hall, Gardner Lindzey, John B. Campbell, Teorie osobowości (Warszawa: Wydawnictwo PWN, 2004), 52-91.

7 Tamże, 96-180; Anna Gałdowa, „Psychologia analityczna C. G. Junga”, w: Klasyczne i wspótczesne koncepcje osobowości, red. Anna Gałdowa (Kraków: Wydawnictwo Uniwersytetu Jagiellońskiego, 1999), 57-86.

${ }^{8}$ Hall, Lindzey, Campbell, Teorie, 451-474. 
ki. Informacje przechowywane są w systemie poznawczym między innymi w postaci schematów oraz skryptów. Treść schematów poznawczych stanowi ważny regulator zachowania człowieka, ukierunkowuje jego działania, umożliwia indywidualną percepcję świata, a także wpływa na przetwarzanie nowych danych ${ }^{9}$.

Jak widać, definicja struktury „Ja” jest niejednoznaczna i związane są z nią liczne wątpliwości. W niniejszej pracy przyjmujemy i będziemy korzystali z definicji sformułowanej przez Bogdana Wojciszke, która brzmi następująco: „Ja jest luźną strukturą różnych ról społecznych, przekonań na własny temat, samoocen oraz wartości i celów uznawanych za własne"10.

\subsection{Funkcje ,Ja”}

Centralną częścią systemu w teorii poznawczej jest pojęcie „Ja”. W literaturze pojęcie „Ja” definiowane jest jako zbiór przekonań o sobie. Dzięki indywidualnemu postrzeganiu ,Ja” człowiek spostrzega siebie jako odrębną jednostkę wyposażoną w indywidualny zestaw cech, doświadczenia, cele. To poczucie jest niezależne od zmieniających się warunków oraz sytuacji1 ${ }^{11}$. Poznawcza reprezentacja „Ja" nazywana jest także samowiedza, autoprezentacją lub struktura „Ja”. Badacze zajmujący się poznawczym ujęciem „Ja” opisują tę strukturę jako: system postaw, ustosunkowań wobec samego siebie $^{12}$, system autoschematów ${ }^{13}$ czy strukturę prototypową ${ }^{14}$.

Punktem wspólnym wymienionych wyżej teorii jest pojmowanie ,ja” jako powiązanego ze sobą zbioru reprezentacji poznawczych przechowywanych w pamięci długotrwałej. Wiedza deklaratywna, na którą składają się takie komponenty jak choćby przekonania dotyczące kompetencji jednostki,

${ }^{9}$ Fecenec, Wielowymiarowy, 6-9.

${ }^{10}$ Bogdan Wojciszke, Człowiek wśród ludzi. Zarys psychologii społecznej (Warszawa: Wydawnictwo Naukowe „Scholar”, 2002), 137.

${ }^{11}$ Fecenec, Wielowymiarowy, 6.

12 Anthony G. Greenwald, A. R. Pratkanis, „«Ja» jako centralny schemat postaw”, Nowiny Psychologiczne 2 (1988): 20-70; Anthony G. Greenwald, Shelly D. Fanham, „Using the implicit association test to measure self-esteem and self-concept", Journal of Personality and Social Psychology 6 (2000): 1022-1038.

13 Fecenec, Wielowymiarowy, 7.

${ }^{14}$ Nicholas A. Kuiper, „Convergent Evidence for the Self as a Prototype: The 'Inverted-U RT Effect' for Self and Other Judgments", Personality and Social Psychology Bulletin 3 (1981): 438-443. 
jej osobistych standardów oraz stanów, jest natomiast elementem opisowego stanu samowiedzy. Drugim składnikiem reprezentacji „Ja” jest tak zwana wiedza proceduralna, czyli nieuświadamiany przez jednostkę zespół procedur oraz reguł, który w swoisty sposób wpływa na identyfikację napływających danych i determinuje ich przetwarzanie. Wiedza zawarta w systemach „ja" stanowi centralną część systemu poznawczego człowieka i ma największy wpływ na przetwarzanie informacji. Informacje dotyczące kwestii ważnych dla jednostki są szybciej wychwytywane przez system poznawczy oraz łatwiej zapamiętywane. Często aktywizowane schematy poznawcze stają się $\mathrm{z}$ czasem chronicznie dostępne, a zatem mają większy wpływ na asymilowanie nowych danych ${ }^{15}$.

Wśród wielu definicji i koncepcji „Ja” jako ważnego elementu samooceny należy wybrać jeden ciagg logiczny, który w praktyczny sposób pomoże pedagogom i osobom udzielającym pomocy zrozumieć elementy tego procesu. Ważnym zagadnieniem, które domagałoby się co najmniej osobnego artykułu jest rola „Ja” w życiu intrapersonalnym jednostki. Pomijając to zagadnienie w niniejszym artykule, odsyłamy zainteresowanych tą tematyką do publikacji z tej dziedziny ${ }^{16}$.

Rozbudowana struktura „Ja” pełni kluczową rolę nie tylko w życiu intrapersonalnym jednostki, ale również $\mathrm{w}$ relacjach interpersonalnych, którymi zajmiemy się w kolejnej części tej pracy. Pomijając zbyt szeroką dla charakteru i celów tej pracy dyskusję nad teoriami i rodzajami tych relacji, przyjmujemy za Strelauem i Dolińskim, iż w kontaktach z innymi wyróżnia się dwie podstawowe funkcje „Ja”: negocjowanie tożsamości oraz symulacje psychiki innych ${ }^{17}$.

Pierwsza funkcja wynika z faktu, iż człowiek nawiązuje wiele interakcji społecznych w codziennym życiu i w każdej z nich jawi się jako jednostka z określoną tożsamością. W zależności od charakteru relacji oraz jej celu człowiek ukazuje różne tożsamości - inne zachowanie przejawia względem rodzica, nauczyciela czy partnera. Owa mnogość tożsamości budujących „Ja” umożliwia jednostce negocjowanie tożsamości w taki sposób, żeby była

15 John A. Bargh, Wendy J. Lombardi, Thory Higgins, „Automaticity of chronically accessible constructs in person x situation effect on person perception: It's just a matter of time", Journal of Personality and Social Psychology 4 (1988): 599-605.

${ }^{16}$ Ronald Benabou, Jean Tirole, ,Self-Confidence and Personal Motivation”, The Quarterly Journal of Economics 3 (2002): 871-915.

17 Jan Strelau, Dariusz Doliński, Psychologia. Podręcznik Akademicki, t. 2 (Gdańsk: Gdańskie Wydawnictwo Psychologiczne, 2008), 316-334. 
jak najbardziej korzystna dla jej mniemania o sobie. Jeśli cenioną wartością jest kariera i awans zawodowy, jednostka może w danej chwili identyfikować się ze swoją tożsamością ,pracownika”, lecz w przypadku zmiany okoliczności może zbliżyć się na przykład do swojej innej tożsamości, takiej jak „matka” lub podobnych, wynikających z realizowanych ról życiowych.

Druga funkcja „Ja” związana z kontaktami interpersonalnymi to symulacja psychiki innych. Podczas relacji z partnerem interakcji niezbędna jest umiejętność odczytywania jego zamiarów, uczuć oraz myśli. Wiele relacji bazuje na skryptach i ma charakter automatyczny, a jednostka kształtuje owe skrypty na bazie poprzednich kontaktów z ludźmi. Jednak nie wszystkie kontakty interpersonalne są do siebie podobne, dlatego osoba musi podejmować wysiłek przewidywania cudzych reakcji. Aby tego dokonać, bazuje na własnych przeżyciach, wspomnieniach, reakcjach i stara się zrekonstruować model psychiki drugiego człowieka. Niestety, takie działanie, choć ułatwia życie społeczne, niepozbawione jest także błędów, takich jak na przykład efekt fałszywej powszechności, gdy człowiek uważa, że inni przejawiają podobne poglądy i zachowania, jakie posiada i przejawia on sam.

Funkcją „Ja” dotyczącą życia intrapersonalnego jest regulacja zachowania celowego. Mowa tu o dokonywaniu wyborów, które możliwe jest dzięki określonym standardom i preferencjom, w jakie wyposażone jest „Ja”. Decyzje podejmowane są w oparciu o swoje postawy, wartości i przekonania o samym sobie, szczególnie w okresach nasilonej autokoncentracji, czyli skupienia się jednostki na sobie. Stan ten może wywoływać jednak nieprzyjemne emocje, dlatego osoba dążąca do przywrócenia optymalnego afektu nie zawsze dokonuje wyborów zgodnych z faktycznym stanem „Ja"18.

Ostatnią funkcją „Ja” jest samokontrola. Dzięki samokontroli możliwa jest zamierzona i dowolna zmiana własnych reakcji. W licznych badaniach dowiedziono, że osoby posiadające umiejętność opierania się pewnym pokusom i impulsom znacznie lepiej radzą sobie w życiu, w okresie szkoły są lepszymi uczniami, a jako osoby dorosłe wiodą bardziej satysfakcjonujące życie rodzinne i rzadziej się rozwodzą. Okazuje się, że deficyty samokontroli stanowią przyczynę agresji, zachowań przestępczych, uzależnień oraz natrętnych ruminacji ${ }^{19}$. Według Baumeistera i współpracowników, przyczyną zmniejszonej samokontroli może być tak zwane wyczerpanie woli, polega-

18 Tamże, 316-334; Paul J. Silvia, „Self-awareness and emotional intensity”, Cognition and Emotion 16 (2002): 195-216.

19 June P. Tangney, Roy F. Baumeister, Angie L. Boone, „High Self-Control Predicts Good Adjustment, Less Pathology, Better Grades, and Interpersonal Success”, Journal of Personality 
jące na spadku poziomu samokontroli u osoby w wyniku niedawnego jej sprawowania $^{20}$.

Wymienione powyżej elementy funkcji „Ja” i ich praktyczna znajomość $\mathrm{w}$ powiązaniu $\mathrm{z}$ zachowaniem jednostki oraz relacjami edukacyjnymi i pomocowymi może stanowić kluczową wskazówkę dla pedagogów. Poprzez oddziaływania pedagogiczne możliwe jest bowiem kształtowanie tożsamości człowieka, pomoc w identyfikowaniu podejmowanych przez niego ról społecznych oraz interakcji z otoczeniem, nauka empatii i współodczuwania. Wyzwaniem dla osób wpływających na proces wychowania jest także oddziaływanie na naukę zachowania celowego związanego z rozwijaniem i wspomaganiem planowania, strategiami podejmowania decyzji oraz realizacją powziętych zadań. Wiedza dotycząca „Ja” może pozytywnie wpłynąć na kształtowanie funkcji samokontroli mającej duże znaczenie w procesie edukacji szkolnej oraz na dalszych etapach rozwoju człowieka w procesie life-long learning.

\section{Jakość samoceny a aktywność zawodowa}

Samoocenę można traktować jako jedną z wielu cech człowieka. Wówczas pojęcie to rozpatruje się w oparciu o określone wymiary. Trzema zasadniczymi wymiarami charakteryzującymi samoocenę są: wysokość, jasność i stałość w czasie. Przyjrzymy się możliwości praktycznego wykorzystania tych wymiarów w pracy edukacyjnej i pomocowej na podstawie analiz, jakie przeprowadzili badacze z dziedziny nauk psychologicznych i pedagogicznych.

Według Leona Niebrzydowskiego, jednostka, u której poziom integracji „Ja” został zahamowany na etapie bezkrytycznego myślenia o swoim zachowaniu oraz nieadekwatnego samozadowolenia, może przyczynić się do powstania tak zwanej samooceny zawyżonej. Brak krytycznej oceny swych zdolności, umiejętności oraz innych cech znaczących może doprowadzić do problemów społecznych oraz zaburzenia samowychowania, co przejawiać się będzie brakiem pracy nad sobą. Natomiast w sytuacji zatrzymania się przez jednostkę na etapie kryzysu integracji spostrzegania własnego

2 (2004): 271-324; Susan Nolen-Hoeksema, Blair E. Wisco, Sonja Lyubomirsky, „Rethinking rumination", Perspectives on Psychological Science 3 (2008): 400-442.

${ }^{20}$ Roy F. Baumeister, Kathleen D. Vohs, Dianne M. Tice, „The Strength Model of SelfControl", Current Directions in Psychological Science 6 (2007): 351-355. 
„Ja” może dojść do wykształcenia się tak zwanej samooceny zaniżonej. Ów stan przejawia się brakiem zadowolenia z siebie, brakiem uznania i szacunku do własnej osoby oraz niewielką wiarą we własne możliwości. W konsekwencji taka percepcja własnej osoby wywołuje u człowieka lęk, niepokój, a nawet autoagresję ${ }^{21}$.

W oparciu o przegląd badań międzynarodowych można stwierdzić, że osoby z wysoką i niską samooceną znacznie różnią się między sobą w kontekście zmiennych psychologicznych, takich jak choćby samopoczucie, zdrowie, emocje, funkcjonowanie w sytuacji zagrożenia ego, zachowania społeczne ${ }^{22}$. Osoby z wysoką samooceną - w przeciwieństwie do jednostek z niskim poczuciem własnej wartości, znajdujących się niejako na przeciwnym krańcu kontinuum - mają bardziej spójną i rozbudowaną samowiedzę, większą pewność sądów na swój temat, a ich samoocena cechuje się większą stabilnością ${ }^{23}$. Różnice te zaznaczają się również w zakresie emocjonalności, samopoczucia oraz zdrowia dwóch omawianych grup. Ludzie cechujący się wysoką samooceną rzadziej odczuwają negatywne emocje, są mniej podatni na depresję, charakteryzują się wyższym poziomem optymizmu w stosunku do przyszłych zdarzeń, wykazują lepsze radzenie sobie ze stresem i samotnością oraz posiadają subiektywnie lepsze samopoczucie oraz poczucie szczęścia ${ }^{24}$. Ludzie $\mathrm{z}$ wysoką samooceną przejawiają także więcej działań prozdrowotnych, prowadzą zdrowszy tryb życia. Osoby z niską samooceną wykazują większą wrażliwość na wpływ codziennych zdarzeń oraz silniejszą tendencję do emocjonalnego reagowania na bodźce, zdecydowanie bardziej pesymistycznie zapatrują się na swoją przyszłość oraz częściej odczuwają u siebie emocje negatywne, lęk i depresję ${ }^{25}$. W podobny sposób osoby

${ }^{21}$ Leon Niebrzydowski, O poznawaniu i ocenie samego siebie: na przykładzie młodzieży dorastajqcej (Warszawa: Wydawnictwo Nasza Księgarnia, 1976), 44-45.

22 John D. Campbell, ,Self-esteem and clarity of the self-concept”, Journal of Personality and Social Psychology 3 (1999): 538-549.

${ }^{23}$ Ann H. Baumgardner, „To know oneself is to like oneself: Self-certainty and selfaffect”, Journal of Personality and Social Psychology 6 (1990): 1062-1072.

${ }^{24}$ Ann L. Story, „Self-esteem and self-certainty: A mediational analysis”, European Journal of Personality 18 (2004): 115-125.

${ }^{25}$ Michelle B. Neiss, Constantine Sedikides, Jim Stevenson, ,,Self-esteem: A behavioral genetic perspective", European Journal of Personality 16 (2002): 351-367; Dean B. McFarlin, Jim Blascovich, „Effects of self-esteem and performance feedback on future affective preferences and cognitive expectations", Journal of Personality and Social Psychology 3 (1981): $521-531$. 
z niską samooceną znajdują się w grupie ryzyka zagrożonej zaburzeniami odżywiania, zwłaszcza bulimią ${ }^{26}$.

\subsection{Poziom samooceny a aktywność zawodowa}

Istotnym elementem $\mathrm{w}$ badaniach psychopedagogicznych jest poziom samooceny. Jej znaczenie w przygotowywaniu i prowadzeniu działań psychopedagogicznych jest znacznie większe, niż narzekanie na wysokie lub niskie ciśnienie atmosferyczne wpływające na procesy edukacyjne i jakość pracy $^{27}$. Wysoki poziom samooceny motywuje jednostki do jej wzmacniania, podejmowania działań ambitnych i ryzykownych, jednak w przypadku przewidywania nieuniknionej porażki - skłania do przerwania podjętego zadania, stając się swoistym regulatorem zachowania. W przypadku porażki osoby te są skłonne do atrybucji zewnętrznej i obwiniania czynników niezwiązanych $\mathrm{z}$ ich cechami ${ }^{28}$. W sytuacji zagrożenia samooceny mogą przejawiać następujące strategie działania: podkreślanie własnych kompetencji, odrzucanie negatywnych informacji zwrotnych, poszukiwanie pozytywnych informacji stanowiących potwierdzenie ich wysokich kompetencji. Należy jednak podkreślić fakt, że w sytuacji zagrożenia ego osoby z wysoką lecz niestabilną samooceną będą skłonne do agresji i wrogości. Osoby z niskim poziomem samooceny wykazują charakterystyki stanowiące przeciwieństwo wyżej opisanych. Na porażkę reagują najczęściej, dokonując atrybucji wewnętrznej, upatrując powodu niepowodzenia we własnej osobie. W sytuacji zagrożenia samooceny wykazują motywację do jej ochrony, skupiają się na poszukiwaniu wsparcia i własnych umiejętnościach społecznych. Często są mniej wytrwałe w wykonywaniu zadań, wykazują też większą ostrożność, wyższy lęk oraz antycypację porażki, a co z tym związane - unikanie sytuacji trudnych. W tej grupie zaznacza się też znaczna dominacja zewnętrznego poczucia kontroli ${ }^{29}$.

${ }^{26}$ Michelle Neiss, Constantine Sedikides, Jim Stevenson, „Genetic influences on level and stability of self-esteem”, Self and Identity 5 (2006): 247-266.

${ }^{27}$ Michael H. Kernis i in., „There's more to self-esteem that weather is it high or low: The importance of stability of self-esteem", Journal of Personality and Social Psychology 6 (1993): 190-204.

${ }^{28}$ Roy F. Baumeister i in, „Does high self-esteem cause better performance, interpersonal success, happiness, or healthier lifestyles?", American Psychological Society 1 (2003): 1-44.

29 Jennifer Crocker, Lora E. Park, ,Seeking self-esteem: Construction, maintenance, and protection of self-worth", Psychological Review 3 (2001): 593-623. 
Co dzieje się w przypadku niskiej samooceny pedagoga lub opiekuna, który rozpoczyna relację edukacyjną lub rozpoczyna proces wsparcia wychowanka? Z badań Baumeistera wynika, że osoby z wysokim poziomem samooceny różnią się od jednostek z niskim poziomem tej cechy również w kontekście kontaktów społecznych. Wykazują większą skłonność do inicjowania kontaktów interpersonalnych. Podczas aktywności w grupie często i chętnie zabierają głos, wysuwają alternatywne pomysły i plany działania. Jednocześnie jednak wykazują tendencje do faworyzowania grupy własnej, mniejszą podatność na perswazję, a także mniejszą obawę przed wygłaszaniem krytyki. Z tego powodu w sytuacjach zagrożenia nierzadko spostrzegane są jako antagoniści, a co za tym idzie - mogą być mniej lubiani przez grupę. Osoby z niskim poziomem samooceny są nieśmiałe w kontaktach międzyludzkich, mają poczucie, iż otrzymują niewielką ilość wsparcia ze strony otoczenia $^{30}$. W trakcie prac grupowych tego typu osoby rzadko zabierają głos i rzadziej niż inni proponują własne pomysły. Ludzie z niską samooceną są bardziej podatni na perswazję, co może mieć związek z większą ilością popełnianych czynów aspołecznych i przestępstw. W sytuacjach zagrażających ich zdrowiu lub życiu osoby te mogą budzić większą sympatię grupy niż jednostki z wysokim poczuciem własnej wartości ${ }^{31}$.

\subsection{Jasność samooceny a aktywność zawodowa}

Tym terminem próbujemy określić autopercepcję osoby oceniającej siebie, co wiąże się także z pojęciami adekwatności czy stabilności. W literaturze psycho-pedagogicznej występuje wiele rozróżnień dotyczących jakościowej charakterystyki samooceny. Tak na przykład: Greenwald i Farnham dokonali rozróżnienia pomiędzy poziomem samooceny jawnej oraz samooceny ukrytej ${ }^{32}$, McFarlin i Blascovich wymieniają samoocenę obronną i autentyczną ${ }^{33}$, Cocker i Park - samoocenę zależną i niezależną ${ }^{34}$, Kernis

${ }^{30}$ Herbert W. Marsh, ,Relations between global and specific domains of self: The importance of individual importance, certainty, and ideas", Journal of Personality and Social Psychology 5 (1993): 975-992.

${ }^{31}$ Baumeister i in., „Does high“, 1-44.

32 Greenwald, Fanham, „Using”, 1022-1038.

${ }^{33}$ McFarlin, Bloscovich, „Effects”, 521-531.

${ }^{34}$ Crocker, Park, ,Seeking”, 593-623. 
opowiada się za istnieniem samooceny stabilnej i niestabilnej ${ }^{35}$, a Niebrzydowski - samooceny adekwatnej i nieadekwatnej ${ }^{36}$. Pomijając złożone debaty teoretyków tego zagadnienia, nie będące przedmiotem tej pracy, spróbujmy w praktyczny sposób wskazać, jak zaburzenia jasności samooceny mogą wpływać na jakość relacji edukacyjnych lub pomocowych.

$\mathrm{W}$ przypadku występowania samooceny niestabilnej u jednostki dochodzi do dezintegracji przejawiającej się występowaniem dwóch skrajnie różnych zachowań. Wówczas ocena „Ja” nie ma charakteru stabilnego, dlatego jednostka uzależnia percepcję własnej osoby od aktualnie przeżywanej sytuacji, sukcesów oraz porażek. Wtedy krytyka powoduje znaczne obniżenie poziomu samooceny, spadek aktywności, natomiast pochwały i sukcesy przyczyniają się do gwałtownego wzrostu poziomu samooceny, a także w konsekwencji - podejmowania działań i zadań nieadekwatnych do psychologicznych możliwości jednostki. Zbliżony mechanizm obserwuje się w przypadku istnienia samooceny nieadekwatnej, gdzie duża rozbieżność pomiędzy „Ja idealnym” i „Ja rzeczywistym” naraża jednostkę na niewłaściwe i nierealistyczne spostrzeganie obrazu „Ja”. Samoocena adekwatna cechuje się natomiast zbliżoną percepcją „Ja idealnego” i „realnego” oraz niezmiennym przypisywaniem sobie określonego zestawu cech, zarówno pozytywnych, jak i negatywnych ${ }^{37}$.

Dla procesu wychowania ważne jest kształtowanie u jednostki samooceny autentycznej i adekwatnej, odnoszącej się do jej realnego funkcjonowania wobec podejmowanych aktywności, sukcesów, porażek. Istotne zdaje się tu rozwijanie u dziecka umiejętności oceny siebie, wglądu we własne poczynania oraz niwelowanie różnicy pomiędzy ,ja” realnym i idealnym, co w efekcie zmniejsza ryzyko podejmowania działań obronnych, mających za zadanie utrzymanie pozytywnego obrazu siebie za wszelką cenę.

\subsection{Stałość samooceny $w$ czasie}

Kolejnym elementem ważnym w pracy edukacyjnej i pomocowej są zmiany percepcji w cyklu życia i rozwoju profesjonalnego. Według wielu autorów, zmiany w poziomie samooceny mogą zachodzić przez całe życie.

${ }^{35}$ Michael H. Kernis, „Measuring self-esteem in context: The importance of stability of self-esteem in psychological functioning”, Journal of Personality 73 (2005): 1569-1605.

36 Niebrzydowski, O poznaniu, 44-45.

37 Tamże, 44-45. 
Dzieje się tak na skutek modyfikacji wiedzy na własny temat i adaptacji do aktualnych warunków przez całe życie, aż do późnej starości ${ }^{38}$. Zdaniem innych badaczy zagadnienia, samoocena kształtuje się od narodzin człowieka, a we wczesnym dzieciństwie do jej kształtowania najbardziej przyczyniają się rodzice dziecka, ich postawy, rodzaj stosowanej komunikacji ${ }^{39}$. W miarę rozwoju jednostka podejmuje nowe aktywności, a ilość źródeł czerpanej wiedzy o sobie znacznie wzrasta. Pozycja zajmowana w grupie rówieśniczej, sukcesy i porażki szkolne, funkcjonowanie w różnych rolach społecznych, stan zdrowia, sytuacja ekonomiczna - wszystkie te czynniki mogą powodować określone wahania poziomu samooceny ${ }^{40}$.

Badania prowadzone na przestrzeni ostatnich dziesięciu lat sugerują, iż poziom samooceny może mieć również podłoże genetyczne ${ }^{41}$. Kluczowym aspektem jest jej względna stabilność (choć, jak wiadomo, zawsze występują wahania ze względu na działanie czynników sytuacyjnych). Jednostki o samoocenie niestabilnej pozostają pod silnym wpływem sytuacji. Wysokość samooceny zależy tu od chwilowych stanów i nastrojów. Pomijając szczegółową analizę złożonych problemów związanych z genetycznymi uwarunkowaniami, należy przyjąć ogólną zasadę, iż w warunkach niekorzystnych dla człowieka jego samoocena ulega gwałtownemu obniżeniu, odwrotnie dzieje się natomiast podczas działania czynników korzystnych ${ }^{42}$. W toku badań potwierdzono przypuszczenie, że największą skłonność do wyrażania gniewu i agresji mają ludzie o samoocenie wysokiej ale niestabilnej. Wiele czynów przestępczych dokonywanych jest przez osoby, które budują swoją samoocenę na bieżąco, a jej poziom uzależniony jest od warunków zewnętrznych. Wówczas o wiele częstszy staje się motyw obronnego wzmacniania tejże cechy ${ }^{43}$.

$\mathrm{Z}$ tego względu tak ważnym elementem procesu wychowania powinno być kształtowanie adekwatnego, względnie stałego poziomu samooceny, który pozostaje niezmienny nawet $\mathrm{w}$ sytuacji trudnej dla jednostki. Czło-

${ }^{38}$ Richard W. Robins, Kali H. Trzesniewski, Jessica L. Tracy, „Global self-esteem cross life span", Psychology and Aging 3 (2002): 423-434.

39 Richard W. Robins, Kali H. Trzesniewski, ,Self-esteem developmental cross the lifespan”, Current Directions in Psychological Science 3 (2005):158-162.

${ }^{40}$ Fecenec, Wielowymiarowy, 9.

${ }^{41}$ Neiss, Sedikides, Stevenson, „Self-esteem”, 351-367; Neiss, Sedikides, Stevenson, „Genetic”, 247-266.

${ }^{42}$ Niebrzydowski, O poznaniu, 47.

${ }^{43}$ Kernis i in., „There's more”, 1190-204. 
wiek przejawiający stabilne poczucie własnej wartości nie musi podejmować działań zaradczych i obronnych o charakterze agresywnym w celu jego ciagłego wzmacniania.

\section{Teorie wyjaśniające znaczenie samooceny dla jakości działań pomocowych}

We współczesnej psychologii i naukach pedagogicznych istnieje wiele teorii wyjaśniających rolę samooceny ${ }^{44}$, wyróżnia się miedzy innymi: samoocene jako ochrone przeciwko stresowi, traumie i nieszczęściom. W tym przypadku samoocena pełni rolę bufora chroniącego człowieka przed skutkami bolesnych wydarzeń, zmniejsza doznawane cierpienie. Im wyższa samoocena tym łagodniejsze skutki doznawania wydarzeń stresowych oraz szybszy powrót do równowagi psychicznej po doświadczeniu sytuacji kryzysowej ${ }^{45}$. Hipoteza ochrony została potwierdzona w licznych badaniach naukowych. De Longis, Folkman i Lazarus potwierdzili hipotezę dotycząca większej ilości symptomów chorobowych w sytuacjach stresujących wydarzeń u osób z niską samooceną ${ }^{46}$. Również w eksperymencie Greenberga i współpracowników dowiedziono, że osoby, którym podwyższano poziom samooceny poprzez wzmacniające komunikaty, wykazywały większą odporność na ekspozycje stresorów takich, jak na przykład makabryczne obrazy śmierci ${ }^{47}$. Pozytywne skutki zawyżania samooceny dla zdrowia psychicznego potwierdzono także w badaniach prowadzonych na grupie mieszkańców Bośni w czasie wojny domowej oraz wśród osób zasiedlających rejony Zatoki San Francisco, które utraciły małżonka w okresie ostatnich trzech lat ${ }^{48}$.

${ }^{44}$ Aleksandra Fila-Jankowska, Samoocena autentyczna. Co ukrywamy sami przed sobq (Warszawa: Wydawnictwo SWPS Academica, 2009).

45 Baumeister i in., „Does high“, 1-44.

${ }^{46}$ Anita De Longis, Susan Folkman, Richard S. Lazarus, „The impact of daily stress on health and mood: Psychological and social resources as mediators", Journal of Personality and Social Psychology 3 (1998), 486-495.

47 Jeff Greenberg, Sheldon Salomon, Thomas Pyszczynski, „Why do people need selfesteem? Converging evidence that self-esteem serves an anxiety-buffering function”, Journal of Personality and Social Psychology 6 (1992): 913-22.

${ }^{48}$ George A. Bonanno i in., ,,Self-Enhancement as a Buffer Against Extreme Adversity: Civil War in Bosnia and Traumatic Loss in the United States", Personality and Social Psychology 88 (2002): 894-898. 
Kolejna grupa koncepcji uznaje samoocene jako socjometr. Przykładem może być teoria stworzona przez Marka Leary'ego ${ }^{49}$, która ma podłoże ewolucyjne i bazuje na przekonaniu, iż samoocena kształtowała się już w czasach, gdy byt człowieka zależał od grupy społecznej. Poza grupą przetrwanie było praktycznie niemożliwe, dlatego u ludzi wykształciła się potrzeba przynależności oraz utrzymywania więzi z innymi członkami społeczności. W obronie tych potrzeb wykształciła się samoocena, która jest miarą bieżącej akceptacji człowieka przez grupę społeczną. Socjometr niejako wychwytuje negatywne informacje mogące sugerować odrzucenie jednostki i sygnalizuje zagrożenie w postaci negatywnej reakcji afektywnej. Wykluczenie przez grupę społeczną prowadzi do obniżenia samooceny oraz wiąże się z uczuciami wstydu ${ }^{50}$.

Szczególnie interesującymi dla osób sprawujących opiekę wydają się teorie określające samoocene jako bufor amortyzujacy lęk przed śmierciq. W koncepcji Pyszczyńskiego, Greenberga i Salomona ${ }^{51}$ człowiek jest jedynym stworzeniem, które zostało wyposażone w lęk przed własną śmiertelnością. U większości społeczeństwa lęk ten nie jest uświadomiony, jednak przejawia się na przykład w poczuciu beznadziejności, braku motywacji. Aby opanować niepożądany stan, ludzie stworzyli wiele kanonów ,prawidłowego" postępowania, światopoglądy oraz wzorce godnego życia według określonego porządku. Życie według zbioru reguł ma zapewnić nieśmiertelność w sensie dosłownym, w postaci życia wiecznego pojmowanego w sensie religijnym oraz w sensie symbolicznym - jako wkład jednostki w kulturę i przetrwanie w postaci jej wytworów. Badania autorów tej teorii pokazały, że myślenie o śmierci wzmaga potrzebę podwyższania poziomu samooceny.

W działaniach edukacyjnych szczególnie przydatne wydają się koncepcje ukazujące samoocene jako mechanizm zapewniajacy optymalnq czujność. Autorami koncepcji tak zwanej optymalnej czujności są Neal Roese i James Olson ${ }^{52}$. Według ich teorii podwyższanie samooceny ma charakter adaptacyjny i wiąże się z mechanizmem afektywnej regulacji. Kwestią kluczową jest tu modyfikowalność sytuacji. Gdy jednostka jest w stanie zmienić zaistniałe warunki poprzez swoje intencjonalne działania, wówczas sy-

49 Mark R. Leary, „Sociometer theory and the pursuit of relational value: Getting to the root of self-esteem",. European Review of Social Psychology 16 (2005): 75-111.

${ }^{50}$ Tamże.

${ }^{51}$ Thomas Pyszczyński i in., ,Why do people need self-esteem? A theoretical and empirical review", Psychological Bulletin 3 (2004), 435-468.

${ }^{52}$ Neal J. Roese, James M. Olson, „Self-esteem and counterfactual thinking”, Journal of Personality and Social Psychology 65 (1993): 199-206. 
tuację można nazwać wysoko modyfikowalną. Zagrożenia przyczyniają się do wystapienia afektu negatywnego, mechanizmy podwyższania samooceny działaja, gdy sytuacja jest słabo modyfikowalna. Ma to w efekcie doprowadzić do stanu pozytywnego afektu oraz umożliwić przejście w stan czujności na wypadek kolejnej porażki czy zagrożenia. W sytuacji, która jest wysoko modyfikowalna, nie występuje podwyższanie samooceny, lecz bezpośrednie działania naprawcze. Zmiana znaku afektu po doznaniu porażki jest niezbędna, aby organizm mógł się bronić przed niepowodzeniami. W przeciwnym razie nastąpiłyby pogłębienie nastroju negatywnego i mniej adaptacyjne reakcje obronne w sytuacji zagrożenia ${ }^{53}$.

\section{Zakończenie}

Zarys roli i funkcji samooceny zarówno w relacjach edukacyjnych, jak i w działaniach pomocowych, w które są zaangażowani pedagodzy, psychologowie i pracownicy socjalni, został przedstawiony w praktyczny sposób dla osób tworzących relacje w tych zakresach. W kontekście poradnictwa psychopedagogicznego niezbędne jest poznanie własnej samooceny oraz wyposażenie się w repertuar zachowań i strategii zaradczych. Przeciwdziałanie obniżeniu samooceny poprzez działania rekompensujące lub wpływające na jej zmianę są w omawianych tu relacjach równie ważne, jak zdefiniowanie lęków i problemów osób edukowanych i otaczanych opieką. W tej sytuacji pomocne okazać się mogą oddziaływania terapeutyczne odnoszące się do systemu wierzeń danego człowieka (na przykład - wyznawana religia, poglądy dotyczące życia po śmierci) oraz motywowanie do rozwoju „Ja” poprzez wytwory o charakterze artystycznym lub naukowym.

Artykuł stanowi próbę przeglądu koncepcji dotyczących samooceny jako ewaluatywnego komponentu struktury „Ja”. Nakreśla role, funkcje oraz składowe tego konstruktu, ukazując ich przydatność dla działań psychopedagicznych. Znajomość znaczenia samooceny dla funkcjonowania jednostki, jej wpływu na zachowanie, afekt, motywację człowieka stanowi kluczowy element wspomagający pracę profesjonalistów zatrudnionych w instytucjach pomocowych. Wnikliwa diagnoza samooceny podopiecznego powinna stanowić fundament oddziaływań psychopedagogicznych i procesu terapeutycznego, którego celem jest poprawa funkcjonowania na płaszczyźnie intra- oraz interpersonalnej.

53 Tamże. 


\section{Self-Esteem of Employees in Educational Institutions and Their Professional Work (Summary)}

Self-esteem plays an important role in every activity associated with interpersonal interaction. It is one of the most important components of the personalities of employees working in helping professions include educational and pedagogical activities. The self-esteem of the educator is a significant starting point that builds relationship teaching or assistance. Formation of self-esteem is the recognition and acceptance of an individual human personality. Self-esteem is one of many structures of "Self" that is analysed by psychology and pedagogy as well. Self and selfesteem have been defined variously by different researchers. Scientists, depending on psychological trend have created many characteristics of those two structures. Their creation and specific functions have been analysed and described. In this article, the authors attempt to show the importance of self-esteem as an evaluative component of the Self structure. The text provides a specific overview of theories and researches made by Polish and international scientists and researchers. Collected data is focused on theoretical issues related to self and self-evaluating. Also, the specific indicators of self-esteem such as its level and fluctuations, stability and clarity of a self-concept are described in the educational context of relationship. All of the mentioned elements affect the activities, intra- and interpersonal relationships of employees working in helping professions.

Key words: self; self-esteem; components of self-esteem; education; professional activity.

\section{Samoocena pracowników w instytucjach edukacyjnych i pomocowych a ich działalność zawodowa (Streszczenie)}

Samoocena pełni istotną rolę w każdej działalności związanej z interakcją międzyludzką. Szczególnie ważna staje się umiejętność samooceny w całej rodzinie zawodów pomocowych (helping professions), do których można zaliczyć zarówno działania edukacyjne i pedagogiczne, jak i wszelkie działania pomocowe. Samoocena osoby edukującej lub pomagającej jest istotnym punktem wyjścia do budowania relacji dydaktycznej lub pomocowej. Kluczowe dla samooceny jest poznanie i zaakceptowanie własnej osobowości, czyli struktury „Ja”, badanych zarówno przez 
psychologię i nauki pedagogiczne, jak również przez inne nauki szczegółowe. Wątpliwości związane z niejednoznaczną definicją struktury „Ja” trwają od bardzo długiego czasu. Badacze, w zależności od nurtu psychologicznego, tworzą różne charakterystyki „Ja”. Dociekania teoretyczne dotyczą zarówno procesu tworzenia się struktury „Ja”, jak i szczegółowych funkcji, które owa struktura pełni. W niniejszym artykule autorzy podejmują próbę odpowiedzi na kluczowe zagadnienia teoretyczne związane z pojęciem samooceny, traktując ją jako ewaluatywny komponent struktury „Ja”. Tekst stanowi swoisty przegląd teorii i badań naukowych poczynionych na gruncie polskim i zagranicznym. Zebrane materiały dotyczą takich wskaźników, jak choćby: zagadnienia teoretyczne związane z pojęciem „Ja” oraz samooceną - jej poziomem, jasnością i stałością, szczególnie w kontekście budowania relacji pomocowej. Te wszystkie elementy wpływają na jednostkę, determinując jej funkcjonowanie na płaszczyźnie intra- i interpersonalnej.

Słowa kluczowe: Ja; samoocena; wskaźniki samooceny; edukacja; działalność zawodowa.

\section{Bibliografia}

Bargh, John A., Wendy J. Lombardi, Thory Higgins. „Automaticity of chronically accessible constructs in person $\mathrm{x}$ situation effect on person perception: It's just a matter of time". Journal of Personality and Social Psychology 4 (1988): 599-605. http://dx.doi.org/10.1037/0022-3514.55.4.599

Baumeister, Roy F. „Ego Depletion and the Self's Executive Function”. W: Psychological perspectives on Self and Identity, red. Abraham Tesser, Richard B. Felson, Jerry M. Suls, 9-33. Washington: APA, 2004.

Baumeister, Roy F. i in. „Does high self-esteem cause better performance, interpersonal success, happiness, or healthier lifestyles?". American Psychological Society 1 (2003): 1-44. http://people.uncw.edu/kozloffm/selfesteembaumeister. pdf

Baumeister, Roy F., Kathleen D. Vohs, Dianne M. Tice. „The Strength Model of Self-Control". Current Directions in Psychological Science 6 (2007): 351-355. http://www-personal.umich.edu/ prestos/Consumption/pdfs/BaumeisterVohs Tice2007.pdf

Baumgardner, Ann H. „To know oneself is to like oneself: Self-certainty and selfaffect". Journal of Personality and Social Psychology 6 (1990): 1062-1072.

Benabou, Ronald, Jean Tirole. „Self-Confidence and Personal Motivation”. The Quarterly Journal of Economics 3 (2002): 871-915. 
Bonanno, George A. i in. ,Self-Enhancement as a Buffer Against Extreme Adversity: Civil War in Bosnia and Traumatic Loss in the United States". Personality and Social Psychology 88 (2002): 894-898. DOI: 10.1177/0146167202282005

Campbell, John D. „Self-esteem and clarity of the self-concept”. Journal of Personality and Social Psychology 3 (1999): 538-549.

Crocker, Jennifer, Lora E. Park. „Seeking self-esteem: Construction, maintenance, and protection of self-worth". Psychological Review 3 (2001): 593-623. http:// dx.doi.org/10.1037/0033-295X.108.3.593

De Longis, Anita, Susan Folkman, Richard S. Lazarus. „The impact of daily stress on health and mood: Psychological and social resources as mediators". Journal of Personality and Social Psychology 3 (1988): 486-495. http://dx.doi. org/10.1037/0022-3514.54.3.486

Fecenec, Diana. Wielowymiarowy Kwestionariusz Samooceny MSEI. Polska adaptacja. Podręcznik. Warszawa: Pracownia Testów Psychologicznych, 2008.

Fila-Jankowska, Aleksandra. Samoocena autentyczna. Co ukrywamy sami przed sobq. Warszawa: Wydawnictwo SWPS Academica, 2009.

Gałdowa, Anna. „Psychologia analityczna C. G. Junga”. W: Klasyczne i współczesne koncepcje osobowości, red. Anna Gałdowa, 57-86. Kraków: Wydawnictwo Uniwersytetu Jagiellońskiego, 1999.

Greenberg, Jeff, Sheldon Solomon, Thomas Pyszczynski. „Why do people need self-esteem? Converging evidence that self-esteem serves an anxiety-buffering function". Journal of Personality and Social Psychology 6 (1992): 913-922.

Greenwald, Anthony G., A.R. Pratkanis. „«Ja» jako centralny schemat postaw”. Nowiny Psychologiczne 2 (1988): 20-70.

Greenwald, Anthony G., Shelly D. Fanham. „Using the implicit association test to measure self-esteem and self-concept". Journal of Personality and Social Psychology 6 (2000): 1022-1038. DOI: 10.1037//0022-3514.79.6.1022I

Hall, Calvin S., Gardner Lindzey, John B. Campbell. Teorie osobowości. Warszawa: Wydawnictwo Naukowe PWN, 2004.

Kernis, Michael H. „Measuring self-esteem in context: The importance of stability of self-esteem in psychological functioning". Journal of Personality 73 (2005): 1569-1605. DOI: 10.1111/j.1467-6494.2005.00359.x

Kernis, Michael H. „Toward a conceptualization of optima self-esteem”. Psychological Inquiry 1 (2003): 1-26. http://academic.udayton.edu/jackbauer/Readings $\% 20595 /$ Kernis $\% 2003 \% 20$ opt $\% 20$ s-esteem $\% 20$ authenticity.pdf

Kernis, Michael H. i in. „There's more to self-esteem that weather is it high or low: The importance of stability of self-esteem". Journal of Personality and Social Psychology 6 (1993): 1190-204. 
Kuiper, Nicholas A. „Convergent Evidence for the Self as a Prototype: The 'Inverted-U RT Effect' for Self and Other Judgments". Personality and Social Psychology Bulletin 3 (1981): 438-443. DOI: 10.1177/014616728173012

Leary, Mark R. „Sociometer theory and the pursuit of relational value: Getting to the root of self-esteem". European Review of Social Psychology 16 (2005): 75-111.

Marsh, Herbert W. „Relations between global and specific domains of self: The importance of individual importance, certainty, and ideas". Journal of Personality and Social Psychology 5 (1993): 975-992.

McFarlin, Dean B., Jim Bloscovich. „Effects of self-esteem and performance feedback on future affective preferences and cognitive expectations". Journal of Personality and Social Psychology 3 (1981): 521-531. http://dx.doi. org/10.1037/0022-3514.40.3.521

Neiss, Michelle, Constantine Sedikides, Jim Stevenson. „Self-esteem: A behavioral genetic perspective". European Journal of Personality 16 (2002): 351-367. http://www.southampton.ac.uk/ crsi/Neiss.Sedikides.Stevenson.2002.EJP.pdf

Neiss, Michelle, Constantine Sedikides, Jim Stevenson. „Genetic influences on level and stability of self-esteem". Self and Identity 5 (2006): 247-266. http://persweb. wabash.edu/facstaff/hortonr/articles $\% 20$ for $\% 20$ class/sedikides $\% 20$ genes $\% 20$ and $\% 20$ self $\% 20$ esteem.pdf

Nolen-Hoeksema, Susan, Blair E. Wisco, Sonja Lyubomirsky. „Rethinking rumination". Perspectives on Psychological Science 3 (2008): 400-442.

Niebrzydowski, Leon. O poznawaniu i ocenie samego siebie: na przykładzie młodzieży dorastajacej. Warszawa: Nasza Księgarnia, 1967.

Pyszczyński, Thomas i in.. ,Why do people need self-esteem? A theoretical and empirical review". Psychological Bulletin 3 (2004): 435-468. DOI: 10.1037/0033 $-2909.130 .3 .435$

Reykowski, Janusz. „Obraz własnej osoby jako mechanizm regulujący postępowanie". Kwartalnik Pedagogiczny 3 (1970): 45-58.

Robins, Richard W., Kali H. Trzesniewski, Jessica L. Tracy. „Global self-esteem cross life span". Psychology and Aging 3 (2002): 423-434. DOI: 10.1037/08827974.17.3.423

Robins, Richard W., Kali H. Trzesniewski. „Self-esteem developmental cross the lifespan". Current Directions in Psychological Science 3 (2005): 158-162. http://www.psy.miami.edu/faculty/dmessinger/c_c/rsrcs/rdgs/emot/robins_trz. selfesteemdevel_curidr2005.pdf

Roese, Neal J., James M. Olson. „Self-esteem and counterfactual thinking”. Journal of Personality and Social Psychology 65 (1993): 199-206.

Schmitt, David P., Juri Alik. „Simultaneous Administration of Rosenberg Self-Esteem Scale in 53 Nations: Exploring the Universal and Culture - Specific Fea- 
tures of Global Self-Esteem". Journal of Personality and Social Psychology 4 (2005): 623-642.

Silvia, Paul J. „Self-awareness and emotional intensity”. Cognition and Emotion 16 (2002): 195-216. http://libres.uncg.edu/ir/uncg/f/P_Silvia_Self_2002.pdf

Story, Ann L. „Self-esteem and self-certainty: A mediational analysis”. European Journal of Personality 18 (2004): 115-125. http://dx.doi.org/10.1002/per.502

Strelau, Jan, Dariusz Doliński. Psychologia. Podręcznik Akademicki, t. 2. Gdańsk: Gdańskie Wydawnictwo Psychologiczne, 2008.

Tangney, June P., Roy F. Baumeister, Angie L. Borne. „High Self-Control Predicts Good Adjustment, Less Pathology, Better Grades, and Interpersonal Success". Journal of Personality 2 (2004): 271-324. http://lazypants.org/dl/files/public/ /TangneyBaumeisterBoone2004.pdf

Wojciszke, Bogdan. „Pogranicze Psychologii osobowości i społecznej: samoocena jako cecha i motyw". W: Osobowość a procesy psychiczne i zachowanie, red. Bogdan Wojciszke, Mieczysław Plopa, 15-47. Kraków: Oficyna Wydawnicza Impuls, 2003.

Wojciszke, Bogdan. Człowiek wśród ludzi. Zarys psychologii społecznej. Warszawa: Wydawnictwo Naukowe „Scholar”, 2002.

Zhang, Liwei. „Prediction of Chinese life satisfaction: Contribution of collective self- esteem". International Journal of Psychology 3 (2005): 189-200. 
